\title{
THE REFORM OF SUPPLY OF PUBLIC HEALTH SERVICES \\ LEADING THE TRAINING OF SPORTS PROFESSIONALS \\ IN LOCAL COLLEGES AND UNIVERSITIES IN THE \\ BACKGROUND OF HEALTHY CHINA
}

Original ArticLe

ARTIGO ORIGINAL

Artículo Original

\author{
A REFORMA DA OFERTA DOS SERVIÇOS DE SAÚDE PÚBLICA NAS ESCOLAS E UNIVERSIDADES LOCAIS NO \\ CONTEXTODACHINASAUDÁVEL
}

\begin{abstract}
LA REFORMA DEL LADO DE LA OFERTA DE LOS SERVICIOS DE SALUD PÚBLICA PARA LA FORMACIÓNDE PROFESIONALES DEL DEPORTE EN LAS UNIVERSIDADES LOCALES EN EL MARCO DE UNA

CHINA SALUDABLE
\end{abstract}

\section{Qiufen $Y u^{1}$ (ID) \\ (Public Health) \\ Baishan Liu' (D) \\ (Social medicine and health \\ management) \\ Jiali Zang' (D) \\ (Basic Medicine) \\ Shujing Wang 1 (D) \\ (Health management) \\ 1. Physical Education College, Qiqihar University, Qiqihar, Heilongjiang Province, China.}

\section{Correspondence:}

Qiqihar, Heilongjiang Province, 161006, China.

ofxhmc@163.com

\begin{abstract}
With the continuous expansion of public health services, the output of sports talents under the existing training mode of sports talents in Colleges and Universities has been unable to meet the market demand of social sports, so it is inevitable to optimize the existing talent training mode. Based on the original "dual system" teaching mode of college sports talents, this study incorporated the LDTA model to optimize and adjust it, so as to establish a new college sports talent training system. In order to prove the feasibility of the new sports talent training system, after analyzing the market economy of the local social sports industry and the basic situation of students, this paper studies the application of the new sports talent training system to the practical teaching of physical education students in 2017 in university X from 2019 to the first half of 2020, and compares the final scores of the students under the original teaching mode and the new sports talent training system. At present, the students' final scores under the new PE talent training system are generally higher than those under the original teaching mode. It is also found that for some practical skills courses, the students' performance under the new PE talent training system is obviously better than that under the original teaching mode. All these results show that the new sports talent training system established by the research is feasible, and has high practical value for promoting the reform of the supply of sports talents in Colleges and Universities and improving the professional skills and knowledge level of sports talents.
\end{abstract}

Keywords: Sports talents; supply side; teaching mode; LDTA model

\section{RESUMO}

Com a contínua expansão do dos serviços de saúde pública, a produção de talentos esportivos sob o modo de treinamento existente em faculdades e universidades não tem atendido a demanda da indústria esportiva social, por isso é inevitável otimizar o modo de treinamento de talentos existente. Baseado no modo de ensino original dual system de talentos esportivos universitários, este estudo utilizou o modelo LDTA para otimizá-lo e ajustá-lo, de modo a estabelecer um novo sistema de treinamento de talentos esportivos universitários. A fim de provar a viabilidade do novo sistema de formação de talentos desportivos, após analisar a economia de bercado da indústria desportiva social local e a situação básica dos estudantes, este documento estuda a aplicação do novo sistema de treinamento de talentos esportivos ao ensino prático dos alunos, em 2017, da escola de educação física da Universidade X de 2019 até a primeira metade de 2020, e compara as pontuações finais dos alunos sob o modo de ensino original e o novo sistema de treinamento de talentos esportivos. Atualmente, as pontuações finais dos estudantes no âmbito do novo sistema de formação de talentos esportivos são geralmente superiores às do modo de ensino inicial. Constata-se também que, para alguns cursos de competências práticas, o desempenho dos estudantes no âmbito do novo sistema de formação de talentos esportivos é obviamente melhor do que o do modo de ensino inicial. Todos esses resultados mostram que o novo sistema de formação de talentos desportivos instituído pela investigação é viável e tem um elevado valor prático para promover a reforma da oferta de talentos desportivos nas faculdades e universidades e para melhorar as competências profissionais e o nivel de conhecimentos dos talentos esportivos.

Descritores: Talento deportivo; suministro lateral; modo de enseñanza; modelo de LDA.

\section{RESUMEN}

Con la continua expansión de los servicios de salud pública, la producción de talentos deportivos bajo el modo de entrenamiento existente en Colegios y Universidades no ha podido satisfacer la demanda del mercado de deportes sociales, por lo que es inevitable optimizar el modo de entrenamiento de talentos existente. Basado 
en el modo de enseñanza original de "sistema dual" de talentos deportivos universitarios, este estudio incorporó el modelo LDTA para optimizarlo y ajustarlo, a fin de establecer un nuevo sistema de entrenamiento de dichos talentos. Con el fin de demostrar la viabilidad del nuevo sistema de formación de talento deportivo, tras analizar la economía de mercado de la industria sociodeportiva local y la situación básica de los estudiantes, este trabajo estudia la aplicación del nuevo sistema de formación de talento deportivo a la docencia práctica de los estudiantes en 2017 del Colegio de Educación Física de la universidad X, y desde 2019 hasta el primer semestre de 2020, y compara los puntajes finales de los estudiantes bajo el modo de enseñanza original y el nuevo sistema de entrenamiento de talento deportivo.. En la actualidad, los puntajes finales de los estudiantes bajo el nuevo sistema de formación de talentos de educación física son generalmente más altos que los del modo de enseñanza original. También se encuentra que, para algunos cursos de habilidades prácticas, el desempeño de los estudiantes bajo el nuevo sistema de formación de talentos de educación física es obviamente mejor que el del modo de enseñanza original. Todos estos resultados muestran que el nuevo sistema de formación de talentos deportivos establecido por la investigación es factible y tiene un alto valor práctico para promover la reforma de la oferta de talentos deportivos en Colegios y Universidades y mejorar las habilidades profesionales y el nivel de conocimiento de los talentos deportivos.

Descriptores: Talento deportivo; suministro lateral; modo de enseñanza; modelo de LDA.

\section{INTRODUCTION}

Since the concept of "healthy China" was first proposed in the Fifth Plenary Session of the 18th CPC Central Committee, public health service has been widely concerned. National fitness has made great contributions to promoting the development of China's health sports industry. ${ }^{1}$ In recent years, with the rising heat of national health problems, the scale of sports industry continues to expand, the sports industry gradually realizes the transformation, the national government's investment in the sports industry is increasing year by year, the demand for sports talents has also begun to change to service-oriented talents, and the demand for sports talents is also rising. However, there are some disjointed problems between the sports talents cultivated by local universities and the market of social sports industry. The supply of sports talents and the quality of sports talents cannot meet the demand of the market. The sports talents exported by colleges and universities to the social market are unitary, which cannot meet the diversified needs of the social market, and their professional knowledge level and practical skills are not well adapted to meet the needs of market economy development. With the development of economic globalization, the economic and cultural exchanges of various countries are increasing. Modern sports is no longer limited to the training of athletes and sports talents, but also integrates various commercial elements and service elements, thus providing an international platform for economic and cultural exchanges of various countries. Therefore, the reform of the supply side of sports talents in Colleges and universities must be put on the agenda. At present, China's sports talents training adopts the "dual system" teaching mode, and pays attention to the learning and education of students' theoretical knowledge and professional practical skills. However, this mode cannot fully meet the diversified talent demand of social sports industry market. Therefore, the supply side reform of sports talents needs to adjust and improve the existing sports talents training mode and methods according to the market demand, so as to make the output quantity, quality and type of sports talents in Colleges and universities meet the needs of different markets to a certain extent and conform to the changes of the times.

In recent years, with the vigorous development of sports, efficient sports personnel training has gradually attracted the attention of national government agencies, and the safety training of sports talents has also attracted the attention of public health service institutions. Andr é ol í MPIO Martins et al. Analyzed and identified the genetic and physiological characteristics of football players by dermatoglyphics, and found that dermatoglyphics can be used as a representative parameter of the potential of a sports player, which can provide certain reference for the selection and cultivation of sports talents. ${ }^{2}$ There was a positive correlation between exercise intensity and endothelium function of athletes. ${ }^{3}$ Bin et al. Introduced computer technology into physical education teaching in Colleges and universities, and found that computer-aided teaching can effectively improve the quality of teaching and help students deepen the development of sports. ${ }^{4}$ Through systematic research and Analysis on the relationship between sports training and peripheral arterial disease. ${ }^{5}$ Parmenter BJ team found that for patients with peripheral artery disease, appropriate exercise can bring benefits to patients collectively. ${ }^{6}$ Based on the analysis of a large number of factual data, kroshus et al. Draw the following conclusion: for college sports athletes after concussion, their early discharge for competition has brought great pressure burden on sports medicine clinicians, and also found that these pressure burdens will affect the nursing and treatment of other patients to a certain extent.? Lampe team studied a legal provision of minimum public health services provided by government agencies in Colorado, and analyzed the collected data by means of mean test, and found that the public health service system played a more important role in the prevention of infectious diseases, the improvement of residents' health level and the protection of environmental health. ${ }^{8}$

To sum up, the accidental injury of sports athletes training has been a major problem faced by the public health service system, and the continuous development of the sports industry promotes the demand for sports talents year by year, so the cultivation and supply of efficient sports talents has become a research hotspot of many researchers. Based on the existing research results, this study will further study and analyze the supply side structure reform of sports talents in Colleges and universities.

\section{The application of college physical education personnel training system in practical teaching of Chinese Universities}

Taking the physical education teaching of X university in Y City of China as the research background, after obtaining the consent of local educational institutions, school teachers and students, this study applies the newly established college sports talent training system to the practical teaching of various majors in the school of physical education of X university. In this study, 2017 grade students were selected as the teaching objects, and the 
practice teaching was carried out in the first half of the academic year of 2019-2020. Based on the establishment of the sports talent training system, before the practice teaching, it is necessary to understand and analyze the specific situation of the students in Y University and physical education college according to the statistics of the relevant data of the students of grade 2017, mainly including the professional setting and curriculum of the physical education college, and the relevant information of the sports students. The statistical results are shown in Table 1.

It can be seen from Table 1 that the school of physical education of $X$ university mainly has three majors: sports training, physical education and social sports. Students' academic tasks in the first half of their junior year are very heavy, including the study of theoretical professional knowledge and the study of various sports skills and technologies. For different majors, the number of hours in the same course is also different. After that, the study analyzed the performance, sports specialty and specialty of different majors. After that, the research analyzes the economic level of social sports industry and the demand market of sports talents in Y City. The internal relationship between the economic scale development and sports industry in Y City is shown in Figure 1. From the chart, we can find that the sports industry income and the urban economic income show a positive correlation trend, which shows that the development of sports industry has a positive impact on the expansion of social and economic scale.

After a preliminary understanding of the school environment and social environment of $X$ university sports students, as well as the basic situation of many students. In this study, the students of each major in 2017 Physical Education Institute were randomly divided into group A (355 people) and group B (365 people) (Figure 1). The teaching of group A follows the original teaching mode and method of the school, while group B carries out practical teaching according to the training system of sports talents. According to the students'social needs, the students in group B are taught according to their social needs. Finally, the final scores of the two groups of P.E. Students in the first half of the 2019-2020 academic year are statistically analyzed, and the results are shown in Table 2.

According to Table 2, the average scores of students in group B are generally higher than those in group A. for some practical teaching, the scores of students in group B are significantly higher than those in group A. These results show that the teaching mode of new sports talent system is helpful to improve the learning achievements of students majoring in physical education. At the same time, it also shows that the new sports talent training system can promote the overall improvement of the level and quality of physical education teaching, and has high practical value and feasibility.

Table 1. Statistics of Sports Major Students.

\begin{tabular}{|c|c|c|c|}
\hline Project & \multicolumn{3}{|c|}{ Statistics of data information } \\
\hline \multirow{4}{*}{$\begin{array}{l}\text { Information statistics } \\
\text { of students majoring } \\
\text { in Physical Education }\end{array}$} & Total & Female & Male \\
\hline & 720 & 315 & 405 \\
\hline & Average age & \multicolumn{2}{|l|}{21} \\
\hline & Sports training stage & \multicolumn{2}{|c|}{ Competitive skills training stage } \\
\hline \multirow{10}{*}{ Major } & Major name & Professional courses & Class hours \\
\hline & \multirow{3}{*}{$\begin{array}{l}\text { Department of } \\
\text { sports training }\end{array}$} & $\begin{array}{c}\text { Theory of sports } \\
\text { training }\end{array}$ & 28 \\
\hline & & Basketball practice & 552 \\
\hline & & Football practice & 552 \\
\hline & \multirow{3}{*}{$\begin{array}{l}\text { Department of } \\
\text { Physical Education }\end{array}$} & Sports Management & 72 \\
\hline & & Exercise physiology & 72 \\
\hline & & Athletics & 72 \\
\hline & \multirow{3}{*}{$\begin{array}{l}\text { Department of } \\
\text { social sports }\end{array}$} & Exercise physiology & 72 \\
\hline & & Basketball & 54 \\
\hline & & Popular football & 54 \\
\hline
\end{tabular}

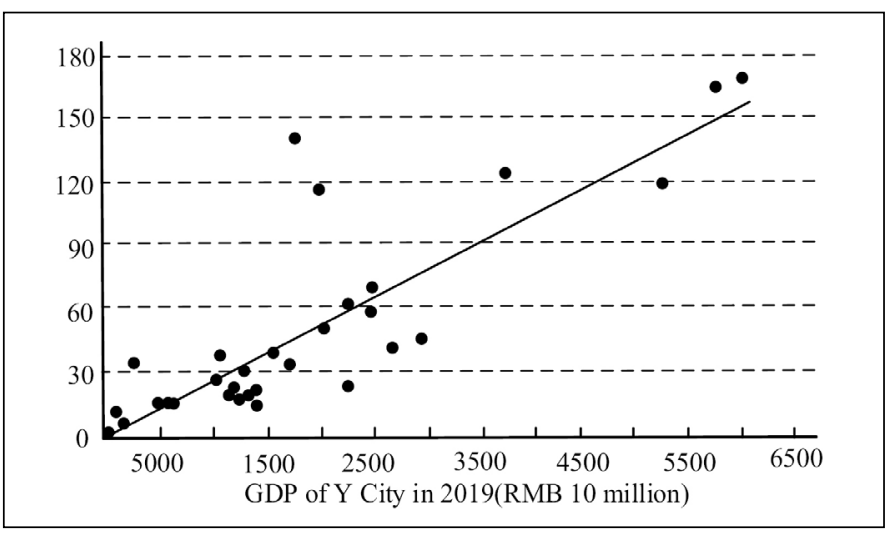

Figure 1. The internal relationship between sports and economic scale in Y City..

Table 2. Final score statistics.

\begin{tabular}{c|c|c|c}
\hline \multirow{2}{*}{ Major name } & Professional courses & \multicolumn{2}{|c}{ Average scores } \\
\cline { 2 - 4 } & & Group A & Group B \\
\hline \multirow{3}{*}{$\begin{array}{c}\text { Department of } \\
\text { sports training }\end{array}$} & Theory of sports training & 75 & 76 \\
\cline { 2 - 4 } & Basketball practice & 84 & 91 \\
\cline { 2 - 4 } & Football practice & 83 & 90 \\
\hline \multirow{2}{*}{$\begin{array}{c}\text { Department of } \\
\text { Physical Education }\end{array}$} & Sports Management & 81 & 87 \\
\cline { 2 - 4 } & Exercise physiology & 78 & 86 \\
\cline { 2 - 4 } & Athletics & 83 & 85 \\
\hline \multirow{2}{*}{$\begin{array}{c}\text { Department of } \\
\text { social sports }\end{array}$} & Exercise physiology & 77 & 81 \\
\cline { 2 - 4 } & Basketball & 72 & 83 \\
\cline { 2 - 4 } & Popular football & 75 & 87 \\
\hline \multicolumn{2}{|c|}{ Average scores } & 78 & 86 \\
\hline
\end{tabular}

\section{CONCLUSIONS}

The widespread concern of national health issues has triggered the rise of national sports health cause. The continuous expansion of the sports industry promotes the increasing demand and quality of sports talents. Therefore, the supply side reform of sports talents in Colleges and Universities has become a research hotspot in the education industry. Based on the analysis of the "dual system" teaching mode in Chinese universities, the ldta model is introduced to create a new sports talent training system. After that, this paper applies this talent training system to the practical teaching of students in the Institute of physical education of $X$ university in $Y$ City of China. Firstly, the students of physical education college are divided into the original teaching mode teaching group (group A) and the new sports talent training mode teaching group (group B). Then, the author makes a comprehensive analysis of some relevant information of the students in the Institute of physical education and the economic situation of the sports market in Y City. The results show that the students in group B are taught in accordance with their aptitude. The comparison of the final scores of the two groups shows that the scores of the students in group B are generally higher, especially for some practical skills courses. The above results show that the use of new sports personnel training system can effectively improve the academic performance of students in Physical Education Institute, but also shows that the new talent training system established by the research has certain feasibility, which can provide a certain practical reference for the cultivation of sports talents in Colleges and universities. Before the application of the new sports talents training system, we need to consider the basic situation of students and the demand of social market, which increases the workload of system implementation to a certain extent, and the realization of intelligent analysis of the system will be the next research focus. 


\section{ACKNOWLEDGEMENT}

1.General project of research on higher education teaching reform in heilongjiang province in 2019,Universities in heilongjiang province under the background of supply-side structural reform of health services Research on the innovation of training mode of applied talents in physical education, No.: SJGY20190738).

2. Basic scientific research operating expenses of heilongjiang provincial undergraduate universities in 2019, Research on diversified supply path and strategy innovation of public service of snow and ice sports tourism in heilongjiang province, No.: 135409337

3.General project of qiqihar science and technology plan 2019 (soft science), Study on the development status and strategic countermeasures of mass ice and snow sports in Qiqihar ,No.: RKX-201918).

All authors declare no potential conflict of interest related to this article

AUTHORS' CONTRIBUTIONS: The author has completed the writing of the article or the critical review of its knowledge content. This paper can be used as the final draft of the manuscript. Each author has made an important personal contribution to this manuscript. Qiufen Yu; Baishan Liu: writing and executing manuscripts. Jiali Zang: data analysis and surgery. Shujing Wang: article reviews and knowledge concepts of articles.

\section{REFERENCES}

1. Peipei S, Chunlin J, Wei T. New medical education reform in China: Towards healthy China 2030 Bioscience Trends. 2017; 11(4):366-369.

2. Martins AO, Soares PM, Godinho WD, Serpa GL, Silva FT. Dermatoglification Analysis for Selection and Training of Sports Talents. IOSR Journal of Pharmacy and Biological sciences. 2017; 12(1):79-83.

3. Ashor AW, Lara J, Siervo M, Celis-Morales C, Oggioni C, Jakovljevic DG, Mathers JC. Exercise Modalities and Endothelial Function: A Systematic Review and Dose-Response Meta-Analysis of Randomized Controlled Trials. Sports Medicine. 2015; 45(2):279-296.

4. Bin T, Weiwei Y. Research on the application of computer assisted instruction in the teaching of physical education in colleges and universities. Agro Food Industry Hi Tech. 2017; 28(1):1533-1537.

5. D Eklund, T Pulverenti, S Bankers, J Avela, R Newton, M Schumann, K Häkkinen. Neuromuscular
Adaptations to Different Modes of Combined Strength and Endurance Training. International Journa of Sports Medicine. 2015; 36(02):120-129.

6. Parmenter BJ, Dieberg G, Smart NA. Exercise Training for Management of Peripheral Arterial Disease: A Systematic Review and Meta-Analysis. Sports Medicine. 2015; 45(2):231-244.

7. Kroshus E, Baugh C M, Daneshvar D H, Julie M Stamm, R Mark Laursen, S Bryn Austin. Pressure on Sports Medicine Clinicians to Prematurely Return Collegiate Athletes to Play after Concussion. Journal of Athletic Training. 2015; 50(9):944.

8. Lampe SMR, Atherly AJ, Vanraemdonck L, Matthews K, Marshall J, Minimum Package of Public Health Services: The Adoption of Core Services in Local Public Health Agencies in Colorado. American Journal of Public Health. 2015; 105(12):1-e8. 